\title{
Determinants of Tax Audit Effectiveness: In Case of Gondar Zone Revenue Offices
}

\author{
Abiy Birlie Adane \\ Business and Economics College, Department of Accounting \& Finance, Mekdela amba University
}

\begin{abstract}
This study was conducted with the aim of identifying the determinants of tax audit effectiveness in Gondar zone revenue offices. Six tax audit effectiveness determinants were examined under four categories; competency of tax auditors, independency of tax auditors, management support, awareness level of taxpayers, attitude of taxpayers towards tax audit, and tax legislation. Tax audit effectiveness is affected by various factors and identifying these factors in order to maintain tax audit effectiveness at satisfactory level and treating the factors accordingly should be the central premises of any tax system. Mixed research approach with explanatory research design is used in the study by employing census survey method to select the participants. The researcher has collected primary data through questionnaires and unstructured interviews. The collected data was analyzed by using STATA11 software and regression and correlations analyses are made to achieve the objectives. Given the ordered ranking of information related to the dependent variable (tax audit effectiveness), ordered logistic regression model is used to identify determinants of tax audit effectiveness in Gondar zone revenue offices. According to the study, factors such as competency of tax auditors, independency of tax auditors, management support, awareness level of taxpayers, attitude of taxpayers towards tax audit were found to be the determinant factors that affect tax audit effectiveness. Finally the study suggested that the office should establish audit center of Excellency, hire competent staff, educate and reward taxpayers to improve the level of tax audit effectiveness.
\end{abstract}

Keywords: tax audit, tax auditor, taxpayers, tax evasion, tax compliance

DOI: $10.7176 /$ RJFA/11-23-03

Publication date: December $31^{\text {st }} 2020$

\section{INTRODUCTION}

\subsection{Background of the study}

States need income sources for the expenditures incurred to deliver and maintain public services. The most important of these income sources are the taxes (Isik, Gelen, \& Sonsuzoglu, 2017). Tax is a mandatory charge imposed by the government without any expectation of quid pro quo. In other words, tax is a compulsory payment by the people to the government for which there is no direct return to the taxpayers. Tax imposes a personal obligation on the people to pay the tax if they are liable to pay it. Taxpayers should be taxed according to their ability to pay, and the people in the same financial position should be taxed in the same way (Parameswaren, 2005). According to the federal income tax proclamation No.979/2016, business income taxpayers are categorized into three categories, namely category "A", "B", and "C" based on their volume of sales and form of business. Category "A" tax payer being a body or any other person having annual gross income of Birr 1,000,000 and more. Those who are categorized under category "A" have to maintain all records and accounts which will enable them to submit a balance sheet and profit \& loss account disclosing the gross profit, general and administrative expenses, depreciation, and provisions and reserves together with supporting vouchers. Category " $\mathrm{B}$ " taxpayer being a person other than a body having annual gross income of Birr 500,000 or more but less than 1,000,000. This category of taxpayers must submit profit and loss statement at the end of the year. The law requires all entries in the records and accounts to be supported by appropriate vouchers. Category " $\mathrm{C}$ " unless already classified in categories " $\mathrm{A}$ " and " $\mathrm{B}$ " include those taxpayers whose annual turnover is estimated by the Tax Authority at Birr 500,000 or less.

Taxes have been acknowledged as a major source of public revenue (Beza, 2014). For that reason, states have been trying to implement and establish dynamic tax systems that will not only ensure the public revenues, necessary for the economic state functioning, but will also enhance citizens' trust towards governments in terms of fairness in the distribution of income tax burdens. Building on the above, tax compliance and tax accounting have been radically changing in most countries worldwide (Colon \& Swagerman, 2015), while tax audit is currently at a crucial stage, because the overall economic growth and increasing regulation all stand to contribute to the ongoing need for audit services ( Karagiorgos, Drogalas, Pazarskis, \& Christodoulou, 2006).

Tax audit involves an examination of taxpayers' business records and financial affairs to ensure taxpayers have computed their tax payable in accordance with the current tax laws and regulations (Isa \& Pope, 2011). Moreover, in a lecture on $24^{\text {th }}$ November, 2016, to 100 medium sized entrepreneurs, Richard said "tax audit is an examination of a taxpayer's business records and financial affairs to ascertain that the right amount of income should be declared and the right amount of tax should be calculated and paid in accordance with tax laws and regulations/ tax compliance". 
Many countries have adopted the self-assessment system (SAS) in order to simplify the tax assessment system and encourage voluntary compliance. Self-assessment system helps to encourage voluntary compliance, reduce tax evasion and make taxpayers more responsible. Under this system, taxpayers are expected to render tax returns based on their income, determine their tax liabilities and pay within the time stipulated by law. In order to sustain the credibility of this system, it is subject to verification by the relevant tax authorities (Ojonta, 2011). In Ethiopia, SAS was recently introduced in 2005 (Niway \& Wondwossen, 2015). During self-assessment tax system (SAS), enforcement activities, in particular tax audit is regarded as the primary strategy taken in ensuring a high level of tax compliance (Singh, 2005).

According to Tadesse \& Goitom (2014), like other developing countries, Ethiopia faces vaults in raising revenue to the required level in order to scale up the development endeavors. Ethiopia has experienced a steadfast expenditure surplus over revenue for a long period of time. Therefore effective tax audit program of revenue body performs a number of important roles and can make a significant contribution to improved administration of the tax system.

According to Ketema (2013), Millions (billions) of Birr are lost through tax evasion every year which leads to excess of public expenditure over public revenues resulting deficit. In addition, taxpayer grievances related to tax audit works result in long delays in collecting the government revenue that is expected to be collected because of the judicial appeal processes. Therefore, it is of great importance to identify the factors affecting tax audit effectiveness in order to achieve tax authority's objectives and to facilitate the tax administration aim of getting "the right tax at the right time." This is the issue that motivates the researcher to do so.

\subsection{Statement of the problem}

Global economic crisis coupled with uncertainty and instability of aid flows has given due attention for governments to look for stable and sustainable modes of development finance (Bhushan \& Samy, 2012). In addition, excessive reliance on foreign financing may in the long run lead to problems of debt sustainability, which together insist on least developed countries to rely substantially on domestic revenue mobilization (Gupta, 2007). One of the best ways which the government can use as a source of revenue is taxation. As in all other countries, one of the purposes of taxation in Ethiopia is the raising of as much revenue as possible to meet the ever-expanding public expenditure for the supply of public goods and services (Ethiopian Chamber of Commerce \& Ethiopian Business Development Services Network, 2005).

A properly designed and administered taxation system is very essential in generating revenue as well as increasing the tax base to the government of developed, developing, and transitional economies. In contrary, under deficient (inadequate) tax administration including insufficient and ineffective audit program, the potential amount of tax revenue in developing and transitional countries has not been collected in a proper and equitable manner. Further, weak tax administration may make the tax system unfair in that honest taxpayers would bear heavier and disproportional burden. It, in turn, may have impact on the efficiency of tax operation, and also may encourage businesses to work in the illegal economy (Edmiston \& Bird, 2004).

According to Mesfin (2008), Weaknesses in revenue administration lead to inadequate tax collections. Revenue shortfalls shrink the budgetary resource envelope, thus, affecting the government's ability to implement its policies and programs and provide public services. Unexpected decline in revenue collections also cause budget cuts that result in major inefficiencies in the public expenditure management. In addition the quality of revenue administration influences the investment climate and private sector development.

In most African countries, the domestic tax bases are undermined by widespread tax avoidance and evasion (IMF, 2011). According to Abreha \& Kahase (2014), tax evasion and avoidance are problems faced by every tax system and the tax system of Amhara National Regional State is not an exception that taxpayers exploit loopholes of tax provisions to minimize or escape tax liability.

According to the Ethiopian Herald interview with Prof. Dr. Fisseha-Tsion Menghistu, "the tax to GDP ratio of Ethiopia is far below the Sub-Saharan average despite many tax reforms since 2002"( Central intelligence agency world fact book and other sources, 2017). This may be as a result of evasion or fraud by the taxpayers which includes; underreporting profits and turnover, underreporting employee wages, failure to register or file tax declarations, dearth of willingness to operate in accordance with tax laws. Netsanet (2014) revealed that like many other jurisdictions, Ethiopia's tax system is fraught with evasion. One factor that significantly contributes to tax evasion is lack of intensive audits and absence of predetermined audit criteria.

There are few researches done on tax audit in Ethiopia. For example Mesfin (2008) tries to assess tax audit practice and its significance in increasing revenue in Ethiopia the case of Addis Ababa city administration by adopting quantitative research design. Another study conducted by Getaneh (2011) tries to examine the tax audit practice in Ethiopia: the case of the federal government. Netsanet (2014) conducted a study on assessment of tax audit practice: the case of Hawassa city administration. A study by Elias (2014) tries to investigate the factors affecting tax audit effectiveness on category " $\mathrm{A}$ " taxpayers in Bahirdar city administration revenue office considering audit quality, organizational setting, support from top management, auditee attributes, and 
organizational independence as determinant factors by adopting quantitative research approach; thus further mixed methods studies by incorporating other factors are needed. Another study conducted by Samuel (2016) tries to assess tax audit practice and its challenges-a case study of Ethiopian revenue and customs authority large taxpayers' office. Recently, Melat (2016) tries to identify factors affecting tax audit effectiveness evidence from large taxpayer's office of Ethiopian revenue and customs authority on auditors' perception.

This study is different from previous researches by the type of research design and approach it adopts as well as by consideration of other determinant factors of tax audit effectiveness. As to the researcher's knowledge enough studies have not been carried out on factors that determine tax audit effectiveness in Gondar zone in particular and Ethiopia in general. This study is done by considering factors like tax auditors' competency, tax auditors' independence, management support, awareness level of taxpayers, attitude of taxpayers and tax legislation. Therefore the purpose of this study is to identify factors that affect tax audit effectiveness in Gondar zone revenue offices by employing mixed research approach to fill the above gap.

\subsection{Objectives of the Study}

\subsubsection{General Objective}

The general objective of the study is to identify the determinants of tax audit effectiveness in Gondar zone revenue offices.

\subsubsection{Specific Objectives}

Specific objectives of the study are:

- To examine the relationship between tax auditors'-related factors (tax auditors' competency, tax auditors' independence) and tax audit effectiveness.

- To find out the effect of organizational-related factors (management support) on tax audit effectiveness.

- To examine the relationship between taxpayers'-related factors (awareness level of taxpayers, attitude of taxpayers) and tax audit effectiveness.

- To determine the effect of regulatory-related factors (tax legislation) on tax audit effectiveness.

- To identify possible measures that should have been taken by the government to improve tax audit effectiveness.

\subsection{Hypothesis Formulation}

In order to answer the research objectives/ questions of the determinants of tax audit effectiveness in Gondar zone revenue offices, the following hypotheses are developed:

- H1: The presence of adequate and competent tax auditors' staff is positively related to tax audit effectiveness.

- H2: Tax auditors' independence is positively related with tax audit effectiveness.

- H3: Management support has a positive effect on tax audit effectiveness.

- H4: There is a significant relationship between awareness level of taxpayers and tax audit effectiveness.

- H5: There is a significant relationship between taxpayers' attitude and tax audit effectiveness.

- H6: The extent of tax legislation has a positive effect on tax audit effectiveness.

\section{RESEARCH METHODOLOGY}

\subsection{Description of the Study Area}

North Gondar zone is a zone in the Ethiopian Amhara region. This zone is named for the city of Gondar, the capital of Ethiopian until the mid- $19^{\text {th }}$ century, which has often been used as a name for the $20^{\text {th }}$ century province of Begemder. North Gondar is bordered on the south by Lake Tana, west Gojjam, Agew Awi, and the BenishangulGumuz region, on the west by Sudan, on the north by Tigray region, on the east by Wag Hemra and on the southeast by south Gondar. Based the new structure the zone is divided in to three namely north Gondar zone (Debark), central Gondar zone (Gondar city) and west Gondar zone (Gendahua). Based on the 2007 census conducted by the central statistical agency of Ethiopia, the zone had a total population of 2,929,628 of whom 1,486,040 are men and $1,443,588$ women with an area of 45,944.63 square kilometers. South Gondar zone is bordered on the south by east Gojjam, on the southwest by west Gojjam and Bahir dar, on the west by Lake Tana, on the north by north Gondar, on the northeast by north Wollo, and on the southeast by south Wollo. Based on the 2007 census conducted by the central statistical agency of Ethiopia, the zone had a total population of 2,051,738 of whom 1,041061 are men and 1,010,677 women with an area of 14,095.19 square kilometers. Towns and cities in south Gondar zone include Debretabour, Addis zemen and Wereta.

\subsection{Research Design and Approach}

Explanatory research design is adopted because as the researcher is going to formulate the relationship between dependent variable (tax audit effectiveness) and independent variables. According to Saunders, Lewis, \& Thronhill (2009), studies that establish causal relationships between variables may be termed explanatory research. The 
emphasis here is on studying a situation or a problem in order to explain the relationships between variables. If the problem calls for the identification of factors that influence an outcome, the utility of an intervention understanding the best predictors of outcomes, then a quantitative approach is best. It is also the best approach to use to test a theory or explanation. On the other hand, if a concept or phenomenon needs to be understood because little research has been done on it, then it merits a qualitative approach (Creswell, 2009). Thus, the type of research employed for this study is mixed research method because either qualitative or quantitative methods are inadequate to best understand a research problem or the strengths of both quantitative and qualitative research can provide the best understanding. This is because the researcher is trying to identify factors that affect tax audit effectiveness (where the use of quantitative method is best) and there are no enough researches done on the issue in Gondar zone (which merits the use of qualitative research method). Therefore, it is better to use mixed research method.

\subsection{Method of Data Collection}

The study used only primary data. Primary data was collected by using structured questionnaires and unstructured interviews. The questionnaire is composed of closed ended and open ended questions. All of the closed ended questions are designed on a Likert-scale. The questions are adopted from previous questions developed by Chalu \& Mzee (2018) and Melat (2016) with some modifications. In order to collect more qualitative data unstructured interviews are employed. This is done by interviewing higher tax officials of the revenue authority.

\subsection{Sample Design}

The target population of this study is Gondar zone revenue office tax auditors and investigation practitioners. The total population under this study is 52 tax auditors. Among these 22 are from central Gondar zone, 12 from south Gondar zone, 10 from north Gondar zone, 8 from west Gondar zone including city administrations. Accordingly, the researcher used census survey method to select respondents from tax auditors of revenue office. Hence, Census method is the most reliable sampling techniques especially if the number of population is small (Kothari, 2004).

\subsection{Method of Data Analysis}

The analysis has been based on descriptive and inferential statistics to provide details regarding the demographic question and the various factors that affect the effectiveness of tax audit by using STATA 11 software. In order to find answers to specific objectives of the study descriptive statistical tools (such as mean, standard deviation, frequency and percentage), and correlation analysis and ordered logistic regression analysis have been done. Data collected from interview was interpreted qualitatively.

\section{DATA ANALYSIS, RESULTS AND DISCUSSION}

\subsection{Introduction}

The previous chapter has discussed appropriate methodologies and the adopted research method for the study along with its rationale. This chapter presents and discusses the empirical results on the determinants of tax audit effectiveness. The study provided two types of data analysis; namely descriptive analysis and inferential analysis. First, the results of descriptive statistics which shows the relevant phenomena of variables such as mean, standard deviation, minimum, maximum of variables used in the study were presented. For the inferential analysis, a regression result of the ordered logistic model which outlines an in-depth examination of the relationship between tax audit effectiveness and the various variables under consideration of the study were discussed and attempts to test the hypothesis.

\subsection{Background information of respondents}

The study has been done by participating 52 tax auditors and investigation practitioners of Gondar zone revenue offices. Questionnaires were distributed to these 52 tax auditors and investigation practitioners and all of them responded. This shows that the response rate was $100 \%$. 
Table 3.1 Demographic characteristics of respondents

\begin{tabular}{|c|c|c|c|c|}
\hline Type & Profile & Frequency & Percentage & cumulative \\
\hline \multirow[t]{3}{*}{ Gender } & Male & 39 & 75 & 75 \\
\hline & Female & 13 & 25 & 100 \\
\hline & Total & 52 & 100 & \\
\hline \multirow[t]{5}{*}{ Age in years } & $18-28$ & 18 & 34.62 & 34.62 \\
\hline & $29-39$ & 26 & 50 & 84.62 \\
\hline & $40-50$ & 7 & 13.46 & 98.08 \\
\hline & Above 50 & 1 & 1.92 & 100 \\
\hline & Total & 52 & 100 & \\
\hline \multirow[t]{5}{*}{ Education level } & Diploma and below & 13 & 25 & 25 \\
\hline & Degree & 39 & 75 & 100 \\
\hline & Master's degree & 0 & 0 & \\
\hline & $\begin{array}{l}\text { Above master's } \\
\text { degree }\end{array}$ & 0 & 0 & \\
\hline & Total & 52 & 100 & \\
\hline \multirow[t]{4}{*}{ Position } & Tax auditor & 46 & 88.46 & 88.46 \\
\hline & Investigation & 6 & 11.54 & 100 \\
\hline & Others & 0 & 0 & \\
\hline & Total & 52 & 100 & \\
\hline \multirow[t]{5}{*}{ Experience } & below 2 year & 10 & 19.23 & 19.23 \\
\hline & $2-5$ year & 29 & 55.77 & 75 \\
\hline & $6-9$ year & 10 & 19.23 & 94.23 \\
\hline & 10 year and above & 3 & 5.77 & 100 \\
\hline & Total & 52 & 100 & \\
\hline \multirow[t]{5}{*}{ Field of study } & Accounting & 34 & 65.38 & 65.38 \\
\hline & Management & 16 & 30.77 & 96.15 \\
\hline & Economics & 2 & 3.85 & 100 \\
\hline & Others & 0 & 0 & \\
\hline & Total & 52 & 100 & \\
\hline
\end{tabular}

Source: (Own computation, 2018)

As shown in the table above, the gender composition was 75 percent males and 25 percent of females. Age profile of the respondents was 34.62 percent (18-28), 50 percent (29-39), 13.46 percent (40-50) and 1.92 percent (above 50 years of age). As it is shown in the table above, the majority of the tax auditors and investigation practitioners fall in the working age group which accounted for 50 percent of the total population.

With regard to educational qualification, the results revealed that the majority of respondents had specialized in accounting as a field of study (about 75 per cent) and the remaining 25 percent of respondents were diploma holders.

Concerning the position of respondents, the result shows that majority of respondents were working as tax auditors which represented about 88.46 percent, while the remaining 11.54 percent of respondents were working as investigation practitioners.

In terms of experience, it could be observed that the majority of respondents insert from two up to five years' of experience (approximately 56 per cent). This is consistent with the number of years respondents had been working with the tax authority whereby those between 6-9 year and below 2 year both formed 19.23 percent, while those with 10 year and above formed 5.77 per cent.

\subsection{Descriptive statistics of dependent and independent variables}

This part of the paper presents descriptive statistics of major variables. It is used to describe the basic features of the data in the study. The table below presents descriptive statistics of the dependent and independent variables of the study. It shows the mean, standard deviation of the variables used in the study. In addition, it shows the minimum and maximum values of each respective variable which essentially gives an indication of how wide ranging each respective variable can be. 
Table 3.2 Descriptive statistic of the variables

\begin{tabular}{|l|l|l|l|l|l|}
\hline & Obs & Mean & Std. dev. & Min & Max \\
\hline Tax audit effectiveness & 52 & 3.726923 & .61616 & 2 & 5 \\
\hline Competency of tax auditors & 52 & 3.507692 & 1.117744 & 1 & 5 \\
\hline Independence of tax auditors & 52 & 3.453846 & .8308893 & 1 & 5 \\
\hline Management support & 52 & 3.233846 & 1.035859 & 1 & 5 \\
\hline Awareness level of taxpayers & 52 & 3.196154 & 1.05272 & 1 & 5 \\
\hline Attitude of taxpayers towards tax audit & 52 & 3.253846 & .9726579 & 1 & 5 \\
\hline Tax legislation & 52 & 3.321154 & 1.515492 & 1 & 5 \\
\hline
\end{tabular}

Source: (Own computation, 2018)

According to Lule- Mert (2016) the mean scores ranges from 1-1.80 were coded as very poor (strongly disagree), 1.81-2.60 poor (disagree); 2.61-3.40, fair (neutral); 3.41-4.20, good (agree); and 4.21-5.00, very good (strongly agree).

From the above table, the mean value related to statements of tax audit effectiveness is 3.726923 . It indicates that majority of the respondents have agreed to the statements provided regarding tax audit effectiveness. The minimum and maximum response values were one and five respectively. Likewise, the value of standard deviation related to tax audit effectiveness statements were 0.61616 which shows respondents perception with regard to the questions are similar.

Competency of tax auditors has a mean of 3.507692 and standard deviation of 1.117744 with minimum and maximum values of one and five respectively. From this it can be understood that majority of the respondents have responded that they were agreed to the statements provided regarding competency of tax auditors.

Independence of tax auditors has a mean of 3.453846 and a standard deviation of 0.8308893 with minimum and maximum response values of one and five respectively. It shows that averaged response of respondents regarding the statement of independence of tax auditors is fair and respondents' responses are somewhat closer with each other.

Management support has a mean of 3.233846 and a standard deviation of 1.035859 with minimum and maximum values of one and five respectively. It indicates that the response of respondents was fair with the statements regarding management support.

The mean value and standard deviation of awareness level of taxpayers was 3.196154 and 1.05272 respectively. It can be understood from the above table that majority of the respondents response was fair with the statements provided regarding awareness level of taxpayers.

Attitude of taxpayers towards tax audit has a mean value of 3.253846 and a standard deviation of 0.9726579 with the minimum and maximum value of one and five respectively. It indicates that the average response of respondents regarding the statement attitude of taxpayers towards tax audit is fair. Since, the mean value ranges from 2.61-3.40.

Tax legislation has a mean of 3.321154 and standard deviation of 1.515492 with minimum and maximum values of one and five respectively. From this it can be revealed that majority of the respondents have responded that they were neutral to the statements provided regarding tax legislation.

\subsection{Analysis of Econometrics Model Regression}

This section deals with analysis of data and interpretation of analytical findings. Initially, it is better to see the overall specification test of the model.

3.4.1 Diagnostics test

Diagnostic tests are robust statistical tests carried out to verify if the data used have met the assumptions underlying the ordinal logistic regression and where possible to remove problems associated with the data. Before estimating the order logistic regression model, it is necessary to check for different method of test such as reliability test, multicollinearity, heteroskedasticity, omitted variable bias, model specification error and outliers.

3.4.1.1 Cronbach's Alpha Test

Cronbach's Alpha is a statistical tool which is used to measure the reliability of a research conducted through the use of questionnaire. A higher alpha is always expected by researchers as it increases the reliability of the research. According to Cronbach's (1951), reliability value $(\alpha)$ greater than 0.6 is also acceptable. As mentioned in the table below, the alpha value for this study is 0.8619 or $86.19 \%$ which is approximately on the higher side and it can be conclude that the questionnaire used in this research is reliable.

Table 3.3 Estimation of Cronbach's alpha

\begin{tabular}{|l|l|}
\hline Cronbach's alpha & Cronbach's alpha based on standardized items \\
\hline 0.8627 & 0.8619 \\
\hline
\end{tabular}

Source: (Own computation, 2018) 


\subsubsection{Test of multicollinearity}

Multicollinearity is the existence of a perfect or exact linear relationship among some or all explanatory or independent variables of the regression model. An important assumption in regression models is that independent variables should not perfectly collinear (one regressor should not be a linear function of another). As Gujarati (2004) noted, indicators of multicollinearity include $\mathrm{R}^{2}$ is very high and none of regression coefficients is statistically significant on conventional t- test and low partial correlation, OLS estimators can have large variances and co-variances and making precise estimation is difficult. To test degree of multicollinearity among explanatory variables of tax audit effectiveness, test of VIF can be employed after running regression. A major problem with multicollinearity is that standard errors may be inflated. Thus, if VIF $>10$ or $1 / \mathrm{VIF}<0.10$ indicates trouble.

Table 3.4: Test of multicollinearity

\begin{tabular}{|l|l|l|}
\hline Variables & VIF & $1 /$ VIF \\
\hline Tax legislation & 2.84 & 0.352707 \\
\hline Awareness level of taxpayers & 1.70 & 0.589040 \\
\hline Independence of tax auditors & 1.50 & 0.667971 \\
\hline Management support & 1.29 & 0.773549 \\
\hline Competency of tax auditors & 1.26 & 0.793618 \\
\hline Attitude of taxpayers & 1.17 & 0.851802 \\
\hline Mean VIF & 1.63 & \\
\hline
\end{tabular}

Source: (Own computation, 2018)

A tolerance level (1/VIF) less than 0.1 and variable inflation factor (VIF) greater than 10 indicates the existence of multicollinearity between the variables. From the above table, there is no problem of multicollinearity between study variables since, the VIF of all variables is less than 10 or $1 /$ VIF is greater than 0.10 .

3.4.1.3 Test of heteroskedasticity

Another important assumption is that the variance in the residuals has to be homoskedastic, which means constant. Residuals cannot vary for lower or higher values of independent variables. In laying out the standard regression model, the researcher made the assumption of homoskedasticity of the regression error term: that is variance is assumed to be constant in the population, conditional on the explanatory variables. The assumption of homoskedasticity fails when the variance changes in different segments of the population. By using Breusch-Pagan / Cook-Weisberg test for heteroskedasticity, there is no any problem of hetroskedasticity since the chi-square is insignificant (chi2 $(1)=1.37$, Prob $>$ chi2 $=0.2410$ ) which the researcher failed to reject the null hypothesis and it can be conclude that there is no problem of heteroskedasticity (Ho: Constant variance).

3.4.1.4 Test of omitted variable bias

Testing for omitted variable bias is important for our model since it is related to the assumption that the error term and independent variables in the model are not correlated $(\mathrm{E}(\mathrm{e} \mid \mathrm{X})=0)$. The null hypothesis is that the model does not have omitted variables bias. According to Ramsey RESET test F $(3,42)=1.45$, Prob $>F=0.2429)$, the $p$ - value is higher than the usual threshold 0.05 , so the researcher failed to reject the null hypothesis and conclude that the researcher do not need more variables. (Ho: model has no omitted variables).

3.4.1.5 Test of model specification error

It basically checks whether the researcher need more variables in the model by running a new regression with observed Y against Yhat and Yhat-squared as independent variables. The thing to look for here is the significance of hatsq. The null hypothesis is there is no model specification error. The p-value of hatsq is not significant $(0.076)$ then the researcher fail to reject the null hypothesis and conclude that our model is correctly specified.

\section{Table 3.5 Test of model specification error}

\begin{tabular}{|c|c|c|c|c|c|c|}
\hline TAE & Coef. & Std.err. & $\mathrm{Z}$ & $\mathrm{P}>|\mathrm{t}|$ & \multicolumn{2}{|c|}{ [95\% Conf. Interval] } \\
\hline hatsq & .3573372 & .1970113 & 1.81 & 0.076 & -.0385717 & .7532462 \\
\hline
\end{tabular}

Source: (Own computation, 2018)

3.4.1.6 Checking outliers

Outliers are data values that differ greatly from the majority of a set of data. These values fall outside of an overall trend that is present in the data. The common sources of outliers are measurement error, human error (errors in data entry and collection), participants intentional reporting of incorrect data, and sampling error. Outliers are data points with extreme values that could have a negative effect on our estimators. To check for outliers the researcher use the added variable plots command after running the regression. 
Fig. 3.1: Checking for outliers
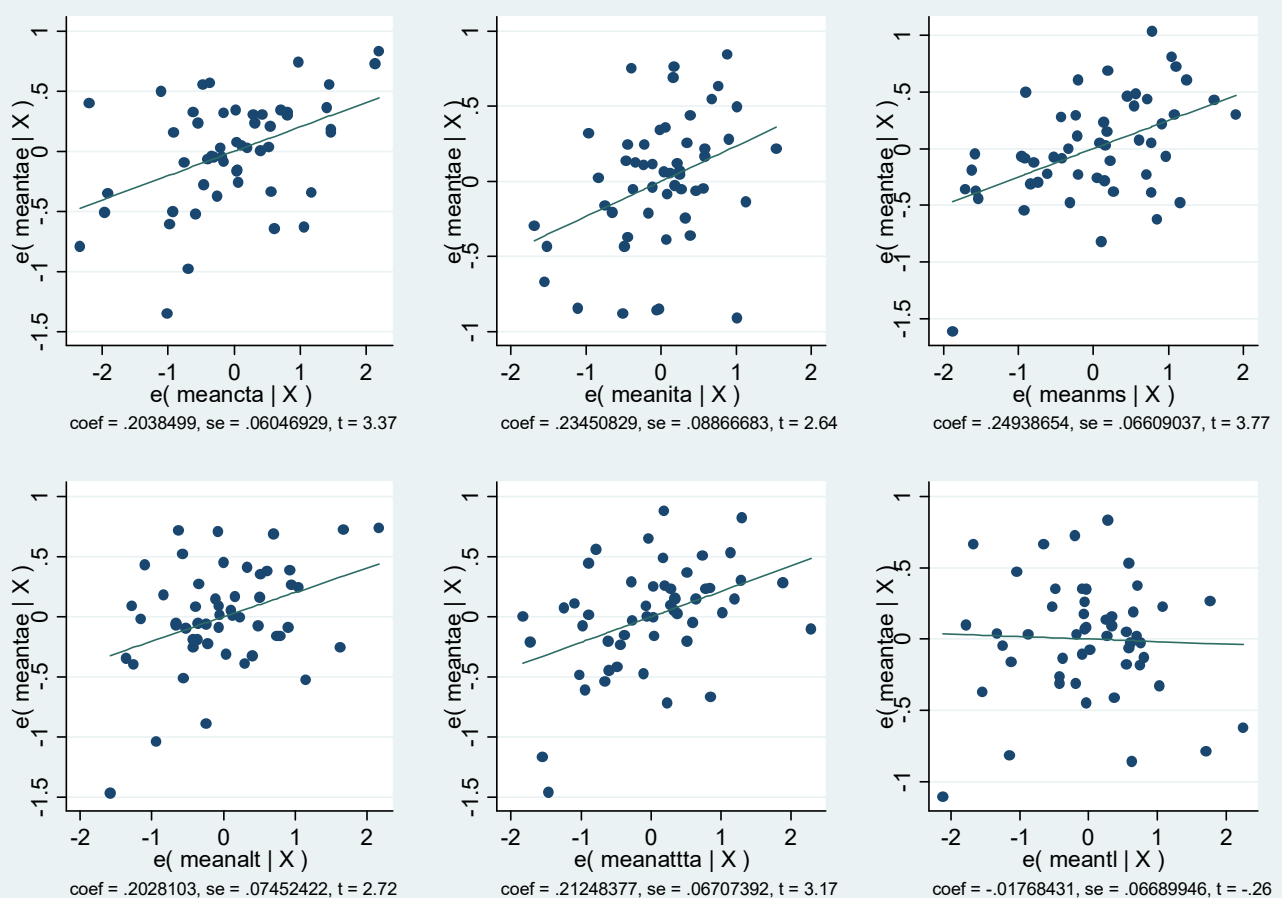

Source: (Own computation, 2018)

The plots regress each variable against all others, notice the coefficients on each. All data points seem to be in range; thus no outliers observed.

\subsection{Correlation among variables}

Spearman's correlation coefficient is a statistical measure which provides a useful and succinct summary of the ordinal association between two variables much more powerfully than the standard Chi-square test (Warner, 2017). Unlike Pearson's correlation, there is no requirement of normality and hence it is a nonparametric statistic. Nonparametric correlation also is less sensitive to outliers than parametric tests.

The following table illustrates the spearman correlation matrix for dependent and independent variables. Based on the table, all independent variables except for tax legislation were positively correlated with tax audit effectiveness. The highest correlation occurred between tax audit effectiveness and attitude of taxpayers towards tax audit $\left(0.3746^{*}\right)$ followed by management support, competency of tax auditors, awareness level of taxpayers, and independence of tax auditors.

Table 3.6: Spearman correlation matrix for dependent, independent variables

\begin{tabular}{|l|l|l|l|l|l|l|l|l|}
\hline \multicolumn{2}{|l|}{} & TAE & CTA & ITA & MS & ALT & ATTTA & TL \\
\hline TAE & Scc & 1.0000 & & & & & & \\
\hline CTA & Scc & 0.3067 & 1.0000 & & & & & \\
\hline ITA & Scc & 0.1846 & -0.2930 & 1.0000 & & & & \\
\hline MS & Scc & 0.3239 & 0.0926 & -0.1402 & 1.0000 & & & \\
\hline ALT & Scc & 0.2550 & -0.0742 & 0.0020 & -0.0805 & 1.0000 & & \\
\hline ATTTA & Scc & 0.3746 & 0.0247 & 0.0315 & -0.0336 & 0.1489 & 1.0000 & \\
\hline TL & Scc & -0.3763 & -0.3169 & 0.4191 & -0.2679 & -0.5105 & -0.2495 & 1.0000 \\
\hline
\end{tabular}

Source: (Own computation, 2018)

Scc- Spearman correlation coefficient

From table 4.6 the researcher started analysis of correlation results between competency of tax auditors and tax audit effectiveness of Gondar zone revenue offices tax auditors. The result of the correlation analysis shows a perfect positive coefficient of 0.3067 . This positive coefficient indicates that when tax auditors who involve in the tax audit activities collectively possess the necessary educational background, knowledge, skills, training and supervision, they will be more likely to conduct their tax audit work properly.

Correlation results between tax audit effectiveness and independence of tax auditors has a positive coefficient of 0.1846 . This result indicates that there is a direct relationship between independence of tax auditors and tax audit effectiveness meaning the more the tax auditors are independent, the greater the tax audit work is effective. 
On the other hand, the results of correlation analysis showed that there was a perfect positive relationship between management support and tax audit effectiveness $(\mathrm{r}=0.3239)$. This positive correlation implies that the greater the support obtained from top management, the greater the effectiveness of tax audit work. In other words, an increase in the level of support of top management tax audit activities facilitate open and direct communications with the manager which enable adequate information flow regarding the activities and plans of the revenue office. Similarly, the results of correlation analysis showed that there is positive correlation between awareness level of taxpayers and tax audit effectiveness $(\mathrm{r}=0.2550)$. This implies that awareness level of taxpayers including the taxpayers' ability to understand taxation laws and regulations, and role of tax on country's economic development influences the compliance level of taxpayers thereby tax audit effectiveness would be affected by awareness level of taxpayers, since there will be significant efforts for tax compliance.

The correlation analysis also showed that there is a perfect positive correlation between attitude of taxpayers towards tax audit and tax audit effectiveness $(\mathrm{r}=0.3746)$. It indicates that those taxpayers who have a positive attitude towards tax audit consider tax audit as a means of deterring malpractices as well as promoting compliance. When a taxpayer has a positive attitude towards tax audit, the taxpayers' inclination to evade tax payments will be reduced.

Finally, the correlation analysis has showed a negative correlation between tax legislation and tax audit effectiveness $(\mathrm{r}=-\mathbf{0 . 3 7 6 3})$. This means that tax legislation cannot be considered as a factor that affects tax audit effectiveness.

\subsection{Ordered logit regression analysis and hypothesis testing}

Under this section the study gave a great emphasis on the order logistic regression models with statistically significant variables and interpreting them by taking their simple logistic coefficient initially and its marginal effects of the outcomes of categorical variables finally.

Table 3.7 Results of ordered logistic regression

\begin{tabular}{|l|l|l|l|l|l|}
\hline TAE & Coef & $Z$ & $\mathrm{P}>\mid \mathrm{Z}$ & \multicolumn{2}{|c|}{$95 \%$ Conf. interval } \\
\hline CTA & $\mathbf{1 . 0 3 9 7 4 3}$ & $\mathbf{3 . 4 2}$ & $\mathbf{0 . 0 0 1}$ & $\mathbf{. 4 4 3 9 4 0 5}$ & $\mathbf{1 . 6 3 5 5 4 6}$ \\
\hline ITA & $\mathbf{1 . 3 6 2 2 0 4}$ & $\mathbf{3 . 2 5}$ & $\mathbf{0 . 0 0 1}$ & $\mathbf{. 5 4 1 9 1 7 3}$ & $\mathbf{2 . 1 8 2 6 5}$ \\
\hline MS & $\mathbf{0 . 9 5 1 2 0 0 3}$ & $\mathbf{3 . 1 5}$ & $\mathbf{0 . 0 0 2}$ & $\mathbf{. 3 6 0 0 7 3 3}$ & $\mathbf{1 . 5 4 2 3 2 7}$ \\
\hline ALT & $\mathbf{0 . 7 5 4 7 1 2 6}$ & $\mathbf{2 . 0 7}$ & $\mathbf{0 . 0 3 8}$ & $\mathbf{. 0 4 1 0 2 6 6}$ & $\mathbf{1 . 4 6 8 3 9 7}$ \\
\hline ATTTA & $\mathbf{0 . 8 2 0 4 8 9 9}$ & $\mathbf{2 . 6 0}$ & $\mathbf{0 . 0 0 9}$ & $\mathbf{. 2 0 2 9 2 7 6}$ & $\mathbf{1 . 4 3 8 0 5 2}$ \\
\hline TL & $\mathbf{- 0 . 2 2 6 8 5 8 1}$ & $\mathbf{- 0 . 8 4}$ & $\mathbf{0 . 4 0 2}$ & $\mathbf{- . 8 9 6 7 7 3 8}$ & $\mathbf{. 3 5 9 6 1 1 8}$ \\
\hline
\end{tabular}

Since, the model (equation) in an ordered logistic model is non-linear, only the signs of the coefficients can be directly interpreted (not their size or magnitude of the coefficient). The results presented in the table indicate that all the independent variables had significant regression coefficients except tax legislation. The regression model as a whole is statistically significant and all the variables are important in the model. Some factors (independent variables) are found to have significant correlation with the dependent variable (tax audit effectiveness). Particularly, the ordered logistic regression results show the existence of statistically significant relationship between tax audit effectiveness and competency of tax auditors, independence of tax auditors, management support, awareness level of taxpayers and attitude level of taxpayers towards tax audit.

With regard to competency of tax auditors, the result of ordered logistic regression shows positive and significant relationship with tax audit effectiveness with a p value of 0.001 . Thus, hypothesis one is accepted and this relationship between competency of tax auditors and tax audit effectiveness is toward the argument that tax audit work will be effective when tax auditors are competent enough to carry out their duties and responsibilities in a proper manner (i.e. as the competence of tax auditors increases, tax audit effectiveness will also increase and vice versa).

Tax auditors' competency is considered as one of the major determinants of tax audit effectiveness. An audit requires a professional staff that collectively has the necessary education, training, experience and professional qualifications to conduct the full range of audits required by its mandate (Elizabeth \& Diane, 2014). Tax audit with educated, experienced and trained auditors is able to enhance tax audit effectiveness. Thus, it is crucial for an auditor to be competent enough to handle audit cases efficiently and furnish himself with technical knowledge, audit skills and analytical thinking. The finding in this research paper is the same as the findings of Wangraj, Ussahawanitchakit, \& Muenthaisong (2007) that is tax audit effectiveness is less achieved if the tax auditors lack adequate knowledge, professional skills, expertise, ethics, proper education and work experience. Similarly, this result is consistent with Hannimitkulchai \& Ussahawanitchakit (2016) who document that providing continuous improvement and lifelong learning will lead to high quality audit report and sustainable audit performance thereby increasing taxpayers' confidence on tax auditors.

With regard to the independence of tax auditors, the study found positive and statistically significant relationship and therefore hypothesis two is accepted. This indicates that the existence of adequate and independent 
tax audit staff plays vital role in assurance of tax audit effectiveness by freely access to necessary documents, information and data relating to the audit work without favor and fear and can evaluate the outcome of the audit report freely and report directly to the responsible body to assure that corrective activities will be taken to implement tax audit recommendations. This finding is consistent with the finding of research done in Tunisia by Hella \& Mohamed (2016). The finding is also supported by Salehi (2016) who found that there is significant positive relation between independence of auditors and audit effectiveness.

The result of the ordered logistic regression shows that there is a positive and significant relationship between management support and tax audit effectiveness. Therefore the hypothesis, there is significant relationship between management support and tax audit effectiveness is accepted. The result is consistent with the study by Elias (2014) and Melat (2016) who has claimed support from top management has direct significant effect on tax audit effectiveness. On the other hand this result is in contradiction with the finding of Baheri, Enam, Kendari, Suawesi, \& Tenggara (2017), who have indicated that the support from top management is not a significant factor explaining tax audit effectiveness that is the role top management could not promote the role of auditors to conduct audit works effectively. Lack of regulation including restriction on auditors' authority in the operational activities, intervention in decision making related to planning and budgeting, and lack of commitment from leaders to strength the internal control unit as well as its responses towards the findings and recommendations became the reason that made the internal control unit could not perform its role effectively.

The result of the ordered logistic regression shows that there is a positive and significant relationship between awareness level of taxpayers and tax audit effectiveness. Therefore the hypothesis, there is significant relationship between awareness level of taxpayers and tax audit effectiveness is accepted. The result is consistent with the study by Suyanto \& Trisnawati (2016) who suggest that the higher the level of awareness of the taxpayers, the taxpayers will be able to determine their behavior better and in accordance with the provisions of taxation so taxpayers have a high compliance rate. Similarly, Oladipupo \& Obazee (2016) states that as awareness level of taxpayers to understand and implement tax obligation increase, the taxpayer tax compliance will also increase and vice versa.

With regard to attitude of taxpayers towards tax audit and tax audit effectiveness, this study founds a positive and significant relationship. Therefore the fourth hypothesis is accepted. The taxpayers' attitudes to tax audit, was found to be positively related to tax audit effectiveness. Attitude is more about taxpayers themselves and how they behave towards tax audit. The findings about taxpayers' attitudes are consistent with previous studies (Gemmell \& Ratto, 2012) which have claimed that taxpayers' attitude can influence tax audit effectiveness.

Finally, the result of the ordered logistic regression shows a statistically insignificant negative relationship between tax legislation and tax audit effectiveness. Therefore, the hypothesis, tax legislation have a positive significant effect on tax audit effectiveness is rejected. This indicates that the tax legislation is not considered as a factor for effectiveness of the tax audit work in the study area. This finding is inconsistent with the finding of Drogalas et al. (2016) and who concludes that complexity of tax legislation is considered as one of the factors that affects noncompliance. Hence audit effectiveness may be adversely affected by complicated tax legislation complexity. And simplicity of a tax system has important attribute for tax audit effectiveness by increasing tax compliance.

\subsection{Ordered logistic regression with marginal effects}

To assess the quantitative effects of the independent variables, marginal effects are calculated. The table below presents the marginal effect of ordered logistic regression for the five categories (strongly agree, agree, neutral, disagree and strongly disagree).

Table 3.8 Marginal effects

\begin{tabular}{|l|l|l|l|l|l|l|l|l|}
\hline \multicolumn{3}{|l}{} & \multicolumn{2}{l}{ P(TAE)=2) } & \multicolumn{2}{l|}{$\mathrm{P}(\mathrm{TAE})=4)$} & \multicolumn{2}{l|}{$\mathrm{P}(\mathrm{TAE})=5)$} \\
\hline & $\mathrm{dy} / \mathrm{dx}$ & $\mathrm{p}>|\mathrm{z}|$ & $\mathrm{dy} / \mathrm{dx}$ & $\mathrm{p}>|\mathrm{z}|$ & $\mathrm{dy} / \mathrm{dx}$ & $\mathrm{p}>|\mathrm{z}|$ & $\mathrm{dy} / \mathrm{dx}$ & $\mathrm{p}>|\mathrm{z}|$ \\
\hline CTA & -.0052021 & 0.339 & -.0288076 & 0.088 & .1206784 & 0.023 & .0223906 & 0.130 \\
\hline ITA & -.0068158 & 0.349 & -.037744 & 0.084 & .1581142 & 0.036 & .0293364 & 0.129 \\
\hline MS & -.0047591 & 0.350 & -.0263544 & 0.092 & .1104016 & 0.030 & .0204838 & 0.139 \\
\hline ALT & -.003776 & 0.379 & -.0209104 & 0.161 & .0875962 & 0.091 & .0162525 & 0.180 \\
\hline ATTTA & -.0041051 & 0.361 & -.0227328 & 0.125 & .0952306 & 0.045 & .017669 & 0.160 \\
\hline TL & .0013438 & 0.527 & .0074414 & 0.429 & -.031173 & 0.432 & -.0057838 & 0.442 \\
\hline
\end{tabular}

Source: (Own computation, 2018)

Once the marginal effects are estimated, the next thing to do is interpreting them. Interpretation of statistically significant dependent variables will be made in the following sections.

In terms of marginal effects, a one point increase in competency of tax auditors is associated with being $0.52 \%$ less likely to disagree with the statements related to tax audit effectiveness, $2.88 \%$ less likely to neutral with the statements related to tax audit effectiveness, $12.06 \%$ more likely agree to the statements related to tax audit 
effectiveness and $22.39 \%$ more likely to strongly agree with the statements related to tax audit effectiveness.

Regarding independence of tax auditors, an increase in independence of tax auditors by one unit is associated with a $0.68 \%$ less likely to disagree and $3.77 \%$ less likely neutral with the statements concerning tax audit effectiveness. On the other hand, it is more likely to the probability of being agree and strongly agree by $15.81 \%$ and $2.93 \%$ respectively.

The marginal effects indicates that a unit increase in management support is associated with a $0.47 \%$ less likely to belong to disagree and $2.63 \%$ less likely to belong to neutral with the statements related to tax audit effectiveness.. Furthermore, it is more likely to the probability of being agree and strongly agree with the statements by $11.04 \%$ and $2.04 \%$ respectively.

In the same vein, marginal effects of one unit increase in awareness level of taxpayers is associated with a decrease in the probabilities of being disagree $(0.37 \%)$ and neutral $(2.09 \%)$. On the other hand it is more likely to belong to agree $(8.75 \%)$ and strongly agree to the statements $(1.62 \%)$.

The marginal effects indicates that an increase in attitude of taxpayers towards tax audit as positive is likely to result in a decrease in the probability of being disagree and neutral with the statements related to tax audit effectiveness by $2.1 \%$ and $2.9 \%$. This also results an increase in the probability of being agree and strongly agree with the statements by 9.52 and $1.76 \%$ respectively.

\subsection{Possible measures to be taken}

Respondents were also given a chance to respond about the problems faced during the course of tax audit work and the possible measures that would be taken by the government (the tax authority). These corrective measures are used to boost or improve the level of tax audit effectiveness. With respect to the problems faced during the course of tax audit work, respondents have responded that lack of proper record keeping by taxpayers, inaccurate reporting including partial submission of books and records for investigation, inadequacy of taxpayers' explanation about their income and expense records, and lack of cooperation of taxpayers, corruption and rent seeking, lack of budget, lack of capability of tax auditors, lack of adequate manpower are some of the problems observed in the study area.

As stated in the literature part, there are two main approaches (i.e. legalistic approach and conciliatory approach) that are used by enforcers as enforcement regulatory style to deal with regulated parties in performing their duties. The legalistic approach relies heavily on penalties and sanctions. This approach was not effective in many developed countries because human beings are not donkeys. The same result was reflected in the study area that strengthening legal enforcement and penalties cannot motivate taxpayers to comply voluntarily. This should not be misinterpreted as if the taxpayers do not want the presence of penalty or legal enforcement, but it simply means penalty or legal enforcement is not the best way to improve tax audit effectiveness. On the other hand, conciliatory approach relies primarily on techniques of education, advice, and persuasion, negotiation, providing necessary information about the utilization of the revenue collected, and making the collection system simple and transparent as motivational factors. The effectiveness of tax audit work mostly depends on tax auditors' actions and reactions to the actual tax audit environment hence tax auditors' behavior and decisions reflect how tax audit work is actually implemented. As majority of the tax auditors responded that main compliance issue among taxpayers was lack of tax and accounting knowledge. Taxpayers may enter in to offences because of lack of knowledge and failure in maintenance of book of accounts and the preparation of tax return, and deductions. Thus, the tax auditors have to educate taxpayers and conduct consultation sessions to resolve disputes. In addition, respondents responded that improving the relation with public, performing audit works in team rather than individually and making the tax law easy and fair are the possible measures that the government (the tax authority) should do to improve tax audit effectiveness in the study area.

\subsection{Interview Results}

As stated in the data collection methods part of the methodology section, unstructured interviews to higher tax officials was employed. This aims at obtaining the relationship between tax audit effectiveness and its determinant factors under consideration of the study. As far as the study is concerned with the issues of determinants of tax audit effectiveness, the interviewed higher tax officials have reflected different ideas.

\section{- Reasons for non-compliance}

With respect to the non-compliance behavior of taxpayers, the interviewees have responded that taxpayers' don't comply because they believe it (tax) is an expense to the business that they try to minimize and because it is costly to comply, taxpayers try to evade taxes. With respect to this issue their expense to maintain books of accounts is high. Additionally, because taxpayers have no enough knowledge about taxation and how to comply, they do not comply with the tax law. If people rightly or wrongly feel that the taxes they pay are either unfair or that they are not properly spent in public services such as building health clinics, schools, and infrastructural projects, and if people rightly or wrongly feel that corruption and rent seeking is high, it is more likely that there is greater probability to avoid their tax liabilities. Generally, lack of ability to pay, lack of awareness, and negative 
perceptions towards tax authority are some of the reason for taxpayers' non-compliance. Similarly there are so many individuals who are engaged in illegal (contraband) trades and all these abnormal acts are hampering taxpayers' business activities and as a result unfair competition and evasion has prevailed. These problems have created distortion in the market and affect taxpayers' attitude towards taxation negatively and this result is the same as the result in the qualitative analysis. Therefore, emphasizing more on strengthening the tax authority capacity, increasing taxpayers' awareness level and building positive taxpayer attitude helps to improve tax compliance and tax audit effectiveness. According to interviewees' response, it is found that tax legislation is not a factor that affect the tax audit effectiveness instead it is affected by failure in its implementation.

\section{- Competency of tax auditors}

As per the interviewees' response, tax auditors' competency and independency are a basis for the overall tax audit performance meaning their technical expertise, communication skill and leadership skill helps to make informed decisions. Competency of tax auditors can be well improved by providing continuous and efficient training. If auditors had a good competency, they would likely to find errors irregularities in the taxpayer tax record and perform their task effectively and efficiently. Interviewees in this study firmly supported the view that tax auditors must independent and must possess the highest possible knowledge and skills. This is because tax auditors' degree of independency and objectivity, and knowledge and skills are directly related to effectiveness of tax audit work.

\section{Measures to be taken}

With regard to the problems faced in the overall tax audit work, as tax auditors almost the same ideas are raised by higher tax officials. Furthermore, one major problem raised by higher tax officials is that taxpayer's mode escapement from paying tax liability using loopholes of tax laws. For instance, those taxpayers particularly large traders who purchase raw materials or inputs from category $\mathrm{C}$ taxpayers are not required submitting legal (official) invoices to the tax authority. In relation to the possible measures that has to be taken by the government (tax authority), the interviewees responded that reducing problems which are encountered in the overall tax audit work requires much more drastic and perhaps unpopular decisions and actions. Moreover, it needs a very cohesive and decisive group of imaginative leaders as well as time to fundamentally transform the tax authority and its image. For the short term, however, what is important is to put the right intelligent tax official at the right place and demand them to start to take some good, bold, and concrete steps in the right direction. It is clear that bringing about fundamental change and transformation in any institution and society is a much more difficult and complex matter that requires many factors including transparency, accountability, visionary, committed, independent and dedicated leadership at all levels of the tax authority. Moreover, interviewees replied that the sector by itself is vulnerable to task for rent seeking. Thus, the concept of one for five structures is a handy solution to reduce these problems. The other point raised by interviewees was that conducting continuous training which focuses on awareness creation and enhances the smooth relationships with business income taxpayers, focusing on changing individuals' attitudes toward the tax system, simplifying the accounting procedure to calculate tax liability and filing returns and develop free record keeping software for the taxpayers, making the tax forms easy to understand and complete, and rewarding taxpayers (giving a trophy for being a best compliant taxpayer) can improve effectiveness of tax audit.

\section{CONCLUSION AND RECOMMENDATION}

This chapter presents conclusions drawn from the overall overviews of the research and its main findings of the analysis part. Then recommendations have been forwarded by the researcher based on the findings made.

\subsection{Conclusion}

It is obvious that tax audit is an important function of tax administration in both developing and developed countries. But the effectiveness of tax audit program depends, among other things, on the tax auditor attributes, organizational factors, taxpayer willingness to comply with tax laws of a country and the nature and scope of legal frameworks in place.

The main objective of this study is to identify the determinants of tax audit effectiveness in Gondar zone revenue offices. To achieve this objective the study adopted mixed research approach. The results of the questionnaire coupled with data obtained from in-depth interviews with higher tax officials of revenue offices were jointly used in analyzing the relationship between tax audit effectiveness and different explanatory variables. The study develops four categories of factors influencing tax audit effectiveness. The four categories were tax auditor-related factors, organizationally related factors, taxpayer-related factors and regulatory-related factors. Through these categories, six hypotheses were formulated and tested using ordered logistic regression analysis model. The tax auditor-related factors comprised two factors, which were competency of tax auditors and independence of tax auditors. The organization-related factor comprised only one factor, which was the management support. Under the taxpayer-related factors, two factors were also identified, which comprised awareness level of taxpayers' and attitude of tax payers towards tax audit. The last category, regulatory-related factors, also had one factor which was tax legislation. 
The results of ordered logistic regression models revealed a statistical relationship between tax audit effectiveness and some of the factors that are considered in the study. Accordingly the findings of this study are presented below.

The results from the ordered logistic regression analysis indicate that, in the case of tax auditors' category, the findings show that competency of tax auditors and independence of tax auditors have a positive significant influence on tax audit effectiveness. It indicates that a tax audit work with educated, experienced, trained and competent auditors is able to improve tax audit effectiveness. Likewise, the result of the regression shows that there is positive and statistically significant relationship between independence of tax auditors and tax audit effectiveness. This indicates that the existence of adequate and independent tax audit staff plays vital role in assurance of tax audit effectiveness by freely access to necessary documents, information and data relating to the audit work without favor and fear and can evaluate the outcome of the audit report freely and report directly to the responsible body to assure that corrective activities will be taken to implement tax audit recommendations.

In organizationally related factors, the finding shows management support has a positive and statistically significant influence on tax audit effectiveness. It implies that the management support in terms of providing resources, giving trainings, introducing with new technologies, providing enough facilities contributes for tax audit effectiveness.

As the ordered logistic regression analysis result revealed that, in the case of taxpayers' category, two factors, awareness level of taxpayers and taxpayers' attitudes towards tax audit, were found to be positively related to tax audit effectiveness.

Under regulatory- category, a finding on the relationship between tax audit effectiveness and tax legislation acknowledges that there is a negative and statistically insignificance relationship between them. This indicates that the tax legislation is not considered as a factor for effectiveness of the tax audit work in the study area.

Finally, the study has tried to identify possible corrective measures that will improve tax audit effectiveness and found that hiring competent and professional tax auditor, educating taxpayers and conduct consultation sessions, improving the relation with public and performing audit works in team rather than individually should be taken in to consideration.

\subsection{Recommendations}

Based on the findings of the study the following recommendations are forwarded that may help the tax authority and other policy makers to improve tax audit effectiveness.

From the study findings it is deduced that tax auditors' competency and independency has a significant effect on tax audit effectiveness. The findings suggest that tax audits with competent and independent staffs are most likely to be effective. Therefore, the revenue offices should provide continuous training to the tax auditors about tax laws, regulations and directives, and specialized computer assisted audit techniques and discussing on different audit cases so as to share experience and facilitate social interactions. In addition the revenue office should have to establish audit center of Excellency to build and surveillance tax auditors' competency and moral principles.

- The study finds strong support for the argument that management support highly affects tax audit effectiveness. The management needs to be strong enough in order to implement the tax authority objectives effectively and efficiently. Functions such as tax assessment, collection, awareness creation, providing information, and enforcement have to be performed effectively and efficiently, so that it will be perceived as strong and powerful by the taxpayers. In the same vein, senior management should support tax auditors in terms of allocating adequate budget, creating good working environment and implementing tax auditor's recommendations.

- $\quad$ From the study finding it can be inferred that awareness level of taxpayers and attitude of taxpayers' towards tax audit have a substantial effect on tax audit effectiveness. The finding suggests that awareness level of taxpayers and attitude of taxpayers towards tax audit as good and positive will increase the effectiveness of tax audit. Therefore, the revenue office should have to educate taxpayers, schedule weekly/monthly meeting with taxpayers, provide information through Radio and TV, magazines, workshops, brushers, newspapers, and houseto-house discussion with taxpayers and reward compliant taxpayers.

- Generally, beside tax auditor and organizational attributes effectiveness of tax audit work partly achieved by the voluntary cooperation of taxpayers. Simply relying only on legalistic approach has no sweeping result. Hence, the government and the tax authority have to capitalize on conciliatory approach in the effort of improving tax audit effectiveness. Tax evasion is unavoidable in each general public or country. Therefore, it is worthwhile to recommend that the above approach has to be supported by legal enforcement style and the efforts must complement each other.

\section{REFERENCES}

Aaron, H., \& Slemrad, J. (2004). The crisis in tax administration. The Brookings Institution, Washington DC. , 17, 387- 402

Abbot, C. (2009). Enforcing pollution control regulation: Strengthening sanctions and improving deterrence. 
Portland, United States of America: Hart Publishing.

Abreha, M., \& Kahase, G. (2014). Income tax assessment procedures and their practical implementations under Amhara National Regional State: Problems and possible solutions, Debre Markos University school of Law.

Agumas, A. (2016). Impact of tax audit on improving taxpayers' compliance: empirical evidence from Ethiopian revenue authority at federal level, Bahirdar University.

Ajzen, I. (2002). Perceived Behavioral Control, Self - Efficacy, Locus of Control, and the Theory of Planned Behavior. Journal of Applied Social Psychology.

Akinbuli, S. (2010). The Effect of Audit Expectation Gap on the Work of Auditors, the Profession and Users of Financial Information. The Nigerian Accountant.

Alleyne, P., \& Howard, M. (2005). An exploratory study of auditors' responsibility for fraud detection in Barbados. Managerial Auditing Journal.

Arena, M., \& Azzone, G. (2009). "Identifying Organizational Drivers of Internal Audit Effectiveness": International Journal of Auditing, Vol. 13, 43-60.

Arens, A., Elder, J., \& Beasley, S. (2012). Auditing and assurance service: an integrated approach, $14^{\text {th }}$ edition.

Awe, O. (2008). The theory and practice of auditing, Lagos: Gilgal Publications.

Badara, M. (2017). The Relevant of Contingency Theory and Stewardship Theory on the Internal Audit Research. Journal of World Economic Research. Vol. 6, No. 2, 2017, pp. 17-22.

Baheri, J.,Sudarmanto, \& Wekke, I. (2017). The effect of management support to effectiveness of internal audit for public universities. Journal of Engineering and Applied sciences 12(7): 1696-1700, 2017.

Beza, M. (2014). Determinants of Taxpayer's Voluntary Compliance with Taxation in East Gojjam, Ethiopia. The International journal's Research Journal of Economics and Business Studies, 9(9).

Bhushan, A., \& Samy, Y. (2012). Aid and taxation: Is Sub-Saharan Africa different? North South Institute Research Report.

Biber, E. (2010). Revenue administration: Taxpayer audit- development of effective plans. Bulletin of International Monetary Fund Fiscal Affairs Department.

Bitrus, G. (2014). Tax audit and minimum tax computation.

Central intelligence agency world fact book and other sources. (2017). Ethiopian economy.

Chalu, H. \& Mzee, H. (2018). Determinants of tax audit effectiveness in Tanzania, Managerial Auditing Journal, Vol. 33 Issue: 1, pp.35-63

Cohen, A, \& Sayag, G. (2010). The Effectiveness of internal auditing: An empirical examination of its determinants in Israeli organizations. Australian Accounting Review.

Colon, D., Swagerman, D. (2015). Enhanced relationship preparedness in a Dutch multinational context: A tax control framework

Cox, S. \& Eger, R. (2006). Procedural complexity of tax administration: The road fund case. Journal of Public Budgeting, Account. Financial Management.

Creswell, J. (2009). Research Design: Qualitative, Quantitative and Mixed methods approaches (3rd ed.). Los Angeles, United States of America: SAGE Publications, Inc.

Cronbach, L (1951). Coefficient alpha and the internal structure of tests.

Dittenhofer, M. (2001). Internal audit effectiveness: an expansion of present methods:

Drazin, R., \& Van de Ven, H. (1985). Alternative forms of fit in contingency theory. Administrative Science Quarterly, 30, 514-539.

Drogalas, G., Ioannis, S., Dimitra, K., \& Ioannis, D. (2015). Tax audit effectiveness in Greek firms: Tax auditors' perceptions.

Edmiston, K., \& Bird, M. (2004). "Taxing Consumption in Jamaica: The GST and SCT"e, IPT Paper No.0414, International Tax Program, Rotman School of Management, University of Toronto.

Elias, A. (2014). Factors affecting tax audit effectiveness, a study on category A tax payers in Bahirdar city administration revenue office, Bahirdar university.

Elizabeth, M. \& Diane, V. (2014). A Global Assessment Based on The IIA's 2010 Global Internal Audit Survey

Erten, S. (2002). Research on about Energy Saving of Intention toward the Behaviour at Homes for Male and Female Students by the Application of the Theory of Planned Behaviour. Hacettepe University Journal Education.

Ethiopian Chamber of Commerce \& Ethiopian Business Development Services Network. (2005). Taxation in Ethiopia: Direct and Indirect Taxes - Categories of Tax Payers Declaration of Income and Assessment of Taxes Tax Incentives, Addis Ababa.

Eugene, N. (2011). Improving revenue collection through tax audit practice: the case of Ghana revenue authority. Federal Negarit Gazette. (2016). Income tax proclamation 979/2016, FDRE: Addis Ababa.

Frey, B. (2003). "Deterrence and Tax Morale in the European Union". European Review.

Gemmell, N., \& Ratto, M. (2012). Behavioral responses to taxpayer audits: evidence from random taxpayer inquiries. National Tax Journal, Vol. 65 No. 1, pp. 33-57. 
Getaneh, M. (2011). Tax audit practice in Ethiopia: the case of the federal government, Addis Ababa University. Grilli, L., \& Rampichini, C. (2015). Ordered logit model.

Gujarati, D. (2003). Basic econometrics $4^{\text {th }}$ edition, US military academy, West point.

Gupta, A. (2007). Determinants of tax revenue efforts in developing countries. International Monetary Fund Working Paper No. 184.

Gwilliam, A (2014). factors affecting the internal audit effectiveness a survey of the Saudi public sector. Journal of international accounting, auditing and taxation 23, 74- 86.

Haldma, T., \& Laats, K. (2002). Contingencies influencing the management accounting practices of Estonian manufacturing companies. Management Accounting Research, 13, 379-400.

Hannimitkulchai, K., \& Ussahawanitchakit, P. (2016). Continuous audit development and audit survival: Evidence from tax auditors in Thailand.

Hella, D. \& Mohamed, A. (2016). Factors Affecting the Internal Audit Effectiveness in Tunisian

Organizations

IMF. (2011). Revenue Mobilization in Developing Countries, Prepared by the Fiscal Affairs Department.

Isa, k., \& Pope, J. (2011). Corporate Tax Audits: Evidence from Malaysia, Global Review of Accounting and Finance.

Isik, H., Gelen, S., \& Sonsuzoğlu, E. (2017). Restructuring of Turkey Tax Audit Units.

Jackson, R. \& Milliron, C. (1986). Tax compliance research: findings, problems, and prospects. Journal of Accounting Literature, Vol. 5 No. 1, pp. 125-165.

James, S. Sawyer, A., \& Wallschutzky, I. (2015). Tax simplification: A review of initiatives in Australia, New Zealand and the United Kingdom.

Karagiorgos, T., Drogalas, G., Pazarskis, M., \& Christodoulou, P. (2006).Conceptual framework, development trends and future prospects of internal audit.

Ketema, T. (2013). The Legal and Institutional Framework for the Regulation of Tax Avoidance and Evasion in Ethiopia, MSc. Thesis, AAU

Kirchler, E., Hoelzl, E., \& Wahl, I. (2008). Enforced versus voluntary tax compliance: The "slippery slope" framework .Journal of Economic Psychology.

Kothari, C. (2004). Research Methodology, Methods and Techniques $2^{\text {nd }}$ revised ed., Former principal college of commerce, University of Rajasthan, Jaipur (India), new age international (p) ltd publishers.

Leviner, S. (2008). An overview: A new era of tax enforcement - From 'big stick' to responsive regulation. Regulation and Governance.

Malcolm, K., Tilden, M., Coope, S., \& Xie, C. (2009). Assessing the effectiveness of enforcement and regulation, City of London.

McAllister, L. (2009). Dimensions of enforcement style: Factoring in regulatory autonomy and capacity, Legal Studies Research Paper Series No. 09-021, University of San Diego School of Law.

Melat, A. (2016). Factors affecting tax audit effectiveness evidence from large taxpayers office of Ethiopian revenue and customs authority, Addis Ababa university.

Mesfin, G. (2008). Tax audit practice and its significance in increasing revenue in Ethiopia the case of Addis Ababa city administration, Addis Ababa University.

Mohd, R. (2010). Tax knowledge and tax compliance determinants in self-assessment system in Malaysia, University of Birmingham.

Nadiah, H., SitiHajar, M., \& Zarinah, R. (2017). The influence of core competency skills of tax auditors towards their performance.

Netsanet, B. (2014). Assessment of tax audit practice in Hawassa city administration Revenue Authority, Hawassa University.

Niway, A., \& Wondwossen, J. (2015). Determinants of voluntary tax compliance behavior in self - assessment system: Evidence from SNNPRS, Ethiopia.

OECD. (2004). Compliance Risk Management Managing and Improving Tax Compliance.

OECD. (2006). Strengthening Tax Audit Capabilities: General Principles and Approaches strengthening tax audit capabilities

Ogundele, E. (1999). Elements of taxation

Ojonta, B. (2011). Tax Audit and Investigation in Enugu state, Nigeria.

Okonkwo, A. (2014). Critical Evaluation of Tax Audit \& Investigation processes in enhancing Tax Compliance; Being paper presented at the CITN MPTP in Uyo on October 8-9, 2014.

Oladipupo, O., \& Obazee, U. (2016). Tax Knowledge, Penalties and Tax Compliance in Small and and Medium Scale Enterprises in Nigeria. iBusiness, 8, 1-9.

Onwudiwe, O., Odo, C.,\& Onyeozili, C. (2004). Deterrence theory. California: sage.

Palil M. ( 2013) The perception of taxpayers on tax knowledge and tax education with level of tax compliance. Asean journal of economics, management and accounting 1(1). 
Parameswaran, R. (2005). Public Finance and Taxation, Addis Ababa.

Rajaraman, I. (1995). How Tax Complexity and Enforcement Affects the Equity and Efficiency of the Income Tax, NBER Working Paper 5391, December.

Richard, K. (2016, November 24). 100 medium sized entrepreneurs. Tax audit and investigation, Tanzania.

Salehi, T. (2016). Investigation Factors Affecting the Effectiveness of Internal Auditors in the Company: Case Study Iran

Samuel, A. (2016). Assessment of tax audit practice and its challenges-a case study of Ethiopian revenue and customs authority large taxpayers' office, Ethiopian Civil Service University.

Saunders, M., Lewis, P., \& Thornhill, A. (2009). Research methods for business students (5th ed.). London, England: Pearson Education Limited.

Schwartz, M., Dunfee, w., \& kline, J. (2005). Ton at the top An ethics code for directors?. J. Bus. Ethics, 58: 79100.

Shippmann, J., Ash, A., Batjtsta, M., Carr, L., Eyde, L., Hesketh, B., \& Sanchez, J. (2006). The practice of competency modeling. Personnel Psychology.

Singh, V. (2005). Malaysian Taxation: Administrative and Technical Aspect (6th ed.). Selangor: PearsonLongman.

Sridharan, (1999), Linkages between Compliance Costs and Taxpayer Compliance Research in Prospect Theory, Compliance Cost Symposium, Sydney.

Sultan, M. \& Awasthi, R. (2011). Risk-Based Tax Audits Approaches and Country Experiences

Suyanto \& Trisnawati, E. (2016). The influence of tax awareness toward tax compliance of entrepreneurial taxpayers.

Tadesse, G., \& Goitom, A. (2014). Factors influencing taxpayers' compliance with the tax system: An empirical study in Mekelle City, Ethiopia, e Journal of Tax Research, 12(2).

Trivedi, U., \& Shehata, M. (2005). Attitudes, incentives, and tax compliance

Wangraj, P., Ussahawanitchakit, P., \& Muenthaisong, K. (2007). Audit responsibility competency and audit survival: evidence from tax auditors (tas) in Thailand.

Warner, P. (2017). Quantifying association in ordinal data 